\title{
Complementary and Alternative Medicine: Impact of Consciousness Energy Healing Treatment on the Physicochemical and Thermal Properties of 6-Mercaptopurine
}

\author{
Dahryn Trivedii ${ }^{1}$, Mahendra Kumar Trivedi ${ }^{1}$, Alice Branton ${ }^{1}$, Gopal Nayak ${ }^{1}$ and Snehasis Jana ${ }^{2 *}$ \\ ${ }^{1}$ Trivedi Global, Inc., Henderson, USA \\ ${ }^{2}$ Trivedi Science Research Laboratory Pvt. Ltd., Bhopal, India \\ *Corresponding author: Snehasis Jana, Trivedi Science Research Laboratory Pvt. Ltd., Bhopal, India

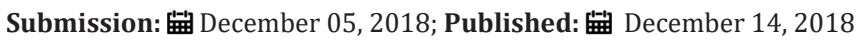

\begin{abstract}
6-Mercaptopurine is a thiopurine-derivative antimetabolite, which is used for the treatment of cancer, ulcerative colitis, Crohn's disease, and autoimmune diseases. The aim of this research work was to evaluate the impact of the Trivedi Effect ${ }^{\circledR}$ on the physicochemical, and thermal properties of 6-mercaptopurine using the modern analytical technique. 6-Mercaptopurine powder sample was divided into two parts. One part of the sample was considered as a control sample (no Biofield Energy Treatment was provided), whereas the other part was treated with Biofield Energy Treatment remotely by a renowned Biofield Energy Healer, Dahryn Trivedi and termed as a treated sample. The particle size values in the treated 6-mercaptopurine powder sample were significantly decreased by $5.72 \%\left(\mathrm{~d}_{10}\right), 5.16 \%\left(\mathrm{~d}_{50}\right), 3.75 \%\left(\mathrm{~d}_{90}\right)$, and $4.54 \%\{\mathrm{D}(4,3)\}$; therefore, the specific surface area was increased by $4.76 \%$ compared to the control sample. The PXRD peak intensities and crystallite sizes of the treated powder sample were significantly altered ranging from-25\% to $14.12 \%$ and $-35.09 \%$ to $71.3 \%$, respectively; whereas the average crystallite size was decreased by $2.77 \%$ compared with the control sample. The latent heat of evaporation and latent heat of fusion of the treated sample was significantly altered by $3.05 \%$ and-39.48\% compared with the control sample. The total weight loss was significantly increased by $9.72 \%$; however, the residue amount was significantly decreased by $79.89 \%$ in the treated sample compared with the control sample. The maximum thermal degradation temperature of the $1^{\text {st }}, 2^{\text {nd }}$, and $3^{\text {rd }}$ peaks of the treated sample was increased by $1.54 \%, 0.13 \%$, and $5.56 \%$ compared with the control sample. From the results, it was concluded that the biofield energy treatment might have generated a new polymorphic form of 6-mercaptopurine which may offer better solubility, dissolution, absorption, and bioavailability compared with the control sample. The Biofield Energy Treated 6-mercaptopurine would be very useful to design better pharmaceutical formulations that might offer better therapeutic response against acute lymphocytic leukemia, chronic myeloid leukemia, ulcerative colitis, Crohn's disease, and autoimmune diseases.
\end{abstract}

Keywords: 6-mercaptopurine; The Trivedi Effect ${ }^{\circledR}$; Consciousness Energy Healing Treatment; Complementary and alternative medicine; Particle size; Surface area; PXRD; DSC; TGA/DTG

\section{Introduction}

Mercaptopurine (1,7-dihydro-6H-purine-6-thione) is a thiopurine-derivative antimetabolite used for the treatment of cancer and autoimmune diseases. The mechanism of action involves inhibition of purine nucleotide synthesis and metabolism by obstructing an enzyme called phosphoribosyl pyrophosphate aminotransferase interference $[1,2]$. It is used alone or with other anti-cancer drugs for the treatment of acute lymphocytic leukaemia, chronic myeloid leukaemia, ulcerative colitis, Crohn's disease, and autoimmune diseases [3-5]. It was listed as Essential Medicines by the World Health Organization and approved for medical use in the USA since from 1953 [6]. Adverse effects associated with the use of 6-mercaptopurine therapy are nausea, vomiting, loss of appetite, diarrhoea, stomach and abdominal pain, mouth sores, fatigue, weakness, fever, sore throat, skin rash, yellowing of skin or eyes, red spots on the skin, darkening of the skin, hair loss, easy bruising or bleeding, black stools, bloody stools, bloody urine, dark urine, painful or difficult urination may suppress the production of both red and white blood cells, and can be linked to the genetic polymorphisms [7-9].

Different mercaptopurine pharmaceutical formulations are available for the oral route of administration are tablets and liquid suspensions [10-12]. The 6-mercaptopurine in water, acetone, chloroform, and diethyl ether is insoluble; slightly soluble in dilute sulphuric acid, but in hot alcohol and dilute alkali solutions it is soluble [12]. In order to improve the solubility, dissolution, absorption, and bioavailability of the pharmaceutical and nutraceutical compounds, scientists throughout the globe doing the extensive research work [13]. On this aspect, the Trivedi Effect ${ }^{{ }_{-}}$ 
biofield energy healing treatment (biofield energy treatment) appealed to have the significant impact on the crystallite size, particle size, surface area, thermal behaviour, and bioavailability profile of pharmaceutical and nutraceutical compounds [14-17]. The Trivedi Effect ${ }^{\circledR}$ is a natural and only scientifically established phenomenon in which an individual can harness this inherently intelligent energy from the "Universe" and transfer it anywhere on the planet through the possible mediation of neutrinos [18]. There is an infinite and Para dimensional electromagnetic field exists surrounding the body of every living organism generated due to continues moment of the charged particle inside the body (i.e., ions, cells, blood flow, etc.) is called Biofield. The Complementary and Alternative Medicine (CAM) therapies has been recognized by the National Centre of Complementary and Integrative Health (NCCIH), which include meditation, yoga, Reiki, hypnotherapy, Ayurvedic medicine, traditional Chinese herbs and medicines in biological systems, etc., that has been accepted by the most of the USA people $[19,20]$. The CAM therapies including Biofield Energy Treatment is an emerging field for the improvement of the quality of life and various health conditions [21,22]. Likewise, the Trivedi Effect ${ }^{\circledR}$-Consciousness Energy Healing Treatment has a significant impact on the physicochemical, structural, and behavioural properties of metals, ceramics, and polymers [23 25], organic compounds [26,27], microorganisms [28,29], cancer cells $[30,31]$, and improve the overall productivity of crops $[32,33]$. Seeing all these outstanding results, the current study was designed to evaluate the influence of the Consciousness Energy Healing Treatment (Trivedi Effect $^{\circledR}$ ) on the physicochemical, thermal, and behavioural properties of mercaptopurine using particle size analysis, powder X-ray diffraction, differential scanning calorimetry, and thermogravimetric analysis/ differential thermogravimetric analysis.

\section{Materials and Methods}

\section{Chemicals and Reagents}

6-Mercaptopurine monohydrate was purchased from Tokyo Chemical Industry Co., Ltd., Japan and the other chemicals were of analytical grade purchased in India.

\section{Consciousness Energy Healing Treatment Strategies}

6-mercaptopurine powder sample was divided into two equal parts. One part of the test sample was treated with the Trivedi Effect $^{\circledR}$ - Consciousness Energy Healing Treatment remotely under standard research laboratory conditions for 3 minutes by the renowned biofield energy healer, Dahryn Trivedi (USA), and known as a Biofield Energy Treated sample. However, the second part of the test sample did not provide Biofield Energy Treatment and considered as a control sample. But the control sample was treated with a "sham" healer and the sham healer totally ignorant about the biofield energy treatment. After the treatment, the treated and untreated samples were kept in sealed conditions and characterized using PSA, PXRD, DSC, and TGA/DTG analytical techniques.

\section{Characterization}

The PSA, PXRD, DSC, and TGA analysis of 6-mercaptopurine were performed. The PSA was performed with the help of Malvern Mastersizer 2000 (UK) using the wet method [34,35]. The PXRD analysis of 6-mercaptopurine powder sample was performed with the help of Rigaku MiniFlex-II Desktop X-ray diffractometer (Japan) $[36,37]$. The average size of crystallites was calculated from PXRD data using the Scherrer's formula (1):

$$
\mathrm{G}=\mathrm{k} \lambda / \beta \cos \theta
$$

Where $\mathrm{G}$ is the crystallite size in $\mathrm{nm}$, $\mathrm{k}$ is the equipment constant, $\lambda$ is the radiation wavelength, $\beta$ is the full width at half maximum (FWHM), and $\theta$ is the Bragg angle [38]. Similarly, the DSC analysis of 6-mercaptopurine was performed with the help of DSC Q200, TA Instruments. The TGA/DTG thermograms of 6-mercaptopurine were obtained with the help of TGA Q50 TA instruments [28,29].

The $\%$ change in particle size, specific surface area (SSA), peak intensity, crystallite size, melting point, latent heat, weight loss and the maximum thermal degradation temperature $\left(\mathrm{T}_{\text {max }}\right)$ of the Biofield Energy Treated sample was calculated compared with the control sample using the following equation 2 :

$$
\% \text { Change }=\frac{[\text { Treated }- \text { Control }]}{\text { Control }} * 100
$$

\section{Results and Discussion}

\section{Particle Size Analysis (PSA)}

Table 1: Particle size distribution and surface area of the control and Biofield Energy Treated 6-mercaptopurine. $d_{10}, d_{50}$, and $\mathrm{d}_{90}$ : particle diameter corresponding to $10 \% 50 \%$ and $90 \%$ of the cumulative distribution, SSA: the specific surface area, and $\mathrm{D}(4,3)$ : the average mass-volume diameter.

\begin{tabular}{|c|c|c|c|c|c|}
\hline Parameter & $\mathbf{d}_{\mathbf{1 0}}(\boldsymbol{\mu} \mathbf{m})$ & $\mathbf{d}_{\mathbf{5 0}}(\boldsymbol{\mu} \mathbf{m})$ & $\mathbf{d}_{\mathbf{9 0}}(\mu \mathbf{m})$ & $\mathbf{D}(\mathbf{4 , 3})(\mu \mathbf{m})$ & $\mathbf{S S A}\left(\mathbf{m}^{2} / \mathbf{g}\right)$ \\
\hline Control & 31.78 & 90.23 & 177.5 & 98.48 & 0.105 \\
\hline Biofield Treated & 29.96 & 85.57 & 170.85 & 94.02 & 0.11 \\
\hline Percent change (\%) & -5.72 & -5.16 & -3.75 & -4.54 & 4.76 \\
\hline
\end{tabular}

The particle size at $d_{10}, d_{50}, d_{90}$, and $D(4,3)$ and surface area analysis of both the control and Biofield Energy Treated mercaptopurine powder samples were performed, and the data are presented in Table 1 . The particle size values of the control powder sample at $d_{10}, d_{50}, d_{90}$, and D $(4,3)$ were $31.78 \mu \mathrm{m}, 90.23 \mu \mathrm{m}$,
$177.5 \mu \mathrm{m}$, and $98.48 \mu \mathrm{m}$, respectively. Likewise, the particle sizes of the treated powder sample at $d_{10}, d_{50}, d_{90}$, and D (4,3) were $29.96 \mu \mathrm{m}, 85.57 \mu \mathrm{m}, 170.85 \mu \mathrm{m}$, and $94.02 \mu \mathrm{m}$, respectively. The particle size values in the treated mercaptopurine powder sample were significantly decreased by $5.72 \%, 5.16 \%, 3.75 \%$, and $4.54 \%$ 
at $d_{10}, d_{50}, d_{90}$, and $D(4,3)$ compared to the control sample. The specific surface area (SSA) of the treated mercaptopurine powder $\left(0.11 \mathrm{~m}^{2} / \mathrm{g}\right)$ was increased by $4.76 \%$ compared to the control sample $\left(0.105 \mathrm{~m}^{2} / \mathrm{g}\right)$. From the result, it can be assumed that the Biofield Energy Treatment might be acting as an external force for the breaking of the larger particles into smaller one, hence increased the surface area. The particle size, shape, and surface area have a huge impact on the solubility, dissolution rate, absorption, bioavailability, and therapeutic efficacy of a pharmaceutical compound $[13,39]$. The solubility of mercaptopurine is very poor in water, chloroform, acetone, and diethyl ether, whereas slightly soluble in dilute sulphuric acid [12]. Therefore, it was predicted that the Biofield Energy Treated 6-mercaptopurine would show the better therapeutic properties by increasing solubility, dissolution, and absorption. It would be better for the pharmaceutical manufacturing industries using it as a raw material for the formulation (Table 1)

\section{Powder X-ray Diffraction (PXRD) Analysis}

The PXRD diffractograms of the control and Consciousness Energy Healing Treated powder samples showed sharp and intense peaks (Figure 1) (Table 2) indicated that both the samples were crystalline. The peak intensities of the Consciousness Energy Healing Treated sample were significantly altered compared to the control sample. Both the control and Biofield Energy Treated samples showed the highest peak intensity at $2 \theta$ near to $27.5^{\circ}$ (Table 2, entry 10). The total peak intensities of the Consciousness Energy Healing Treated sample were significantly altered ranging from $-25 \%$ to $14.12 \%$ compared to the control sample. Similarly, the crystallite sizes of the treated mercaptopurine were significantly altered ranging from $-35.09 \%$ to $71.3 \%$ compared to the control sample. However, the average crystallite size of the Biofield Energy Treated mercaptopurine powder $(299.8 \mathrm{~nm})$ was decreased by $2.77 \%$ compared with the control sample $(299.8 \mathrm{~nm})$.



Figure 1: PXRD diffractograms of the control and Biofield Energy Treated 6-mercaptopurine.

Table 2: PXRD data for the control and Biofield Energy Treated 6-mercaptopurine.

\begin{tabular}{|c|c|c|c|c|c|c|c|c|}
\hline Entry No. & \multicolumn{2}{|c|}{ Bragg angle $\left({ }^{\circ} \mathbf{2}\right)$} & \multicolumn{3}{|c|}{ Peak Intensity (\%) } & \multicolumn{3}{c|}{ Crystallite size (G, nm) } \\
\hline & Control & Treated & Control & Treated & \% change $^{\text {a }}$ & \multicolumn{2}{|c|}{ Control $^{\text {Treated }}$} & \% change $^{\mathbf{b}}$ \\
\hline 1 & 11.7 & 11.74 & 116 & 128 & 10.34 & 311 & 320 & 2.89 \\
\hline 2 & 12.74 & 12.77 & 58 & 48 & -17.24 & 493 & 340 & -31.03 \\
\hline 3 & 14.47 & 14.51 & 307 & 317 & 3.26 & 289 & 288 & -0.35 \\
\hline 4 & 15.26 & 15.28 & 84 & 82 & -2.38 & 333 & 349 & 4.8 \\
\hline 5 & 16.76 & 16.7 & 33.5 & 35.8 & 6.87 & 341 & 354 & 3.81 \\
\hline
\end{tabular}




\begin{tabular}{|c|c|c|c|c|c|c|c|c|}
\hline 6 & 20.48 & 20.44 & 85 & 97 & 14.12 & 271 & 240 & -11.44 \\
\hline 7 & 23.41 & 23.41 & 238 & 221 & -7.14 & 308 & 323 & 4.87 \\
\hline 8 & 25.09 & 25.18 & 192 & 180 & -6.25 & 368 & 342 & -7.07 \\
\hline 9 & 25.74 & 25.75 & 177 & 151 & -14.69 & 304 & 322 & 5.92 \\
\hline 10 & 27.46 & 27.48 & 506 & 480 & -5.14 & 265 & 285 & 7.55 \\
\hline 11 & 29.31 & 29.3 & 170 & 164 & -3.53 & 256 & 263 & 2.73 \\
\hline 12 & 30.3 & 30.32 & 147 & 146 & -0.68 & 299 & 311 & 4.01 \\
\hline 13 & 32.4 & 32.42 & 65 & 64 & -1.54 & 320 & 314 & -1.88 \\
\hline 14 & 33.11 & 33.08 & 48 & 43 & -10.42 & 297 & 286 & -3.7 \\
\hline 15 & 35.18 & 35.17 & 33.5 & 35.9 & 7.16 & 319 & 304 & -4.7 \\
\hline 16 & 35.81 & 35.88 & 64 & 58 & -9.38 & 252 & 264 & 4.76 \\
\hline 17 & 39.34 & 39.35 & 51 & 53 & 3.92 & 315 & 285 & -9.52 \\
\hline 18 & 42.28 & 42.34 & 23 & 26 & 13.04 & 493 & 320 & -35.09 \\
\hline 19 & 46.32 & 46.27 & 40 & 30 & -25 & 218 & 289 & 32.57 \\
\hline 20 & 47.61 & 47.7 & 61 & 59 & -3.28 & & 115 & 197 \\
\hline 21 & & Average crystallite size & & & 31.3 \\
\hline
\end{tabular}

${ }^{a}$ denotes the \% change in the peak intensity of Biofield Energy Treated sample with respect to the control sample; ${ }^{b}$ denotes the \% change in the crystallite size of Biofield Energy Treated sample with respect to the control sample.

The peak intensity of each diffraction face on the crystalline compound changes according to the crystal morphology [40] and alterations in the XRD pattern provide the evidence of polymorphic transitions $[41,42]$. Any change observed in the crystallite sizes and peak intensities indicated the modification of the crystal morphology of the Biofield Energy Treated mercaptopurine compared to the control sample. The Trivedi Effect ${ }^{\circledR}$-Consciousness
Energy Healing Treatment probably produced the new polymorphic form of 6 mercaptopurine through the Biofield Energy via neutrino oscillations [18]. Thus, the treated mercaptopurine might have shown the significant effects on the drug performance, such as bioavailability, therapeutic efficacy, and toxicity, because of their physicochemical properties like melting point, energy, stability, and solubility, are different from the original form $[43,44]$ (Table 2).

\section{Differential Scanning Calorimetry (DSC) Analysis}
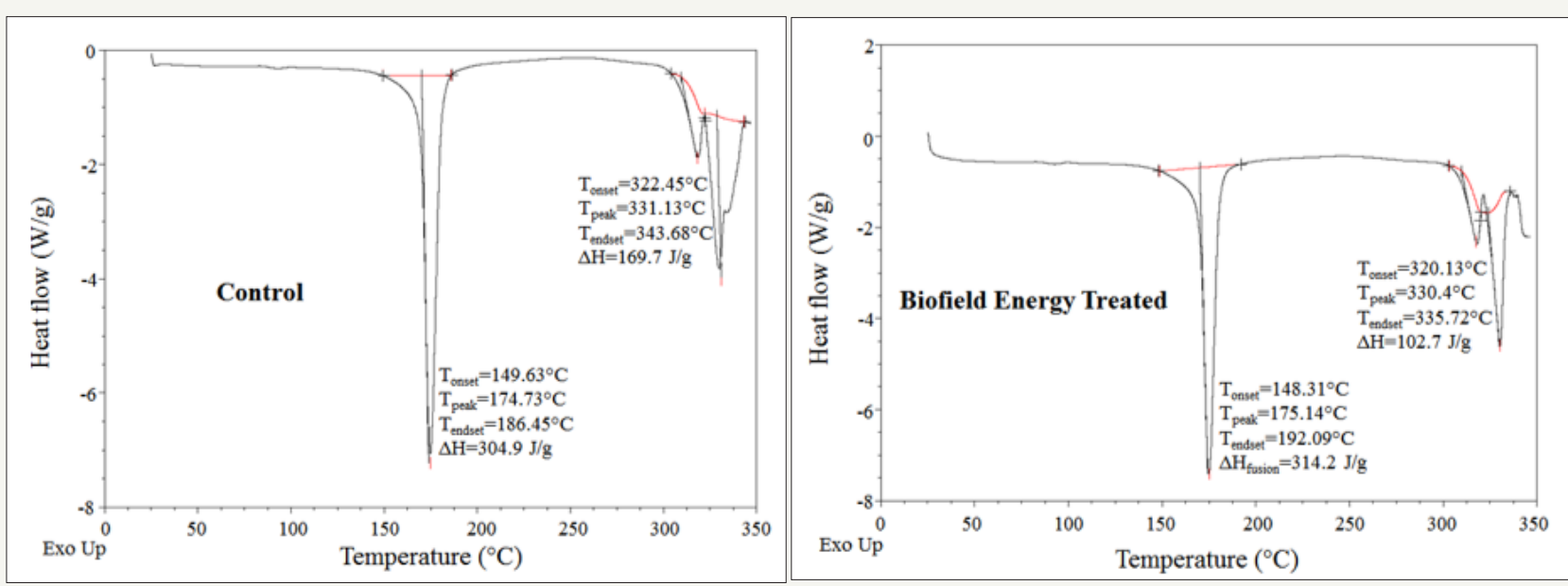

Figure 2: DSC thermograms of the control and Biofield Energy Treated mercaptopurine.

The DSC thermograms of both the control and Biofield Energy Treated sample showed the two sharp endothermic peaks in the thermograms (Figure 2). The control and Biofield Energy Treated samples showed the $1^{\text {st }}$ endothermic peak at $174.73{ }^{\circ} \mathrm{C}$ and 175.14 ${ }^{\circ} \mathrm{C}$, respectively due to the evaporation of the bounded water. Similarly, the $2^{\text {nd }}$ endothermic peak of the control and Biofield Energy Treated mercaptopurine samples was observed at $331.13^{\circ} \mathrm{C}$ and $330.4{ }^{\circ} \mathrm{C}$, respectively indicated the melting point. The thermal analysis data closely matched to the literature reported data [44]. The evaporation temperature and latent heat of evaporation $(\Delta \mathrm{H}$ evaporation) of the Biofield Energy Treated mercaptopurine were slightly increased by $0.23 \%$ and $3.05 \%$, respectively compared with the control sample (Table 3). 
Table 3: DSC data for both control and Biofield Energy Treated samples of mercaptopurine.

\begin{tabular}{|c|c|c|c|c|}
\hline Sample & Evaporation Temp $\left({ }^{\circ} \mathrm{C}\right)$ & Melting Point $\left({ }^{\circ} \mathrm{C}\right)$ & \multicolumn{2}{|c|}{$\Delta \mathrm{H}(\mathrm{J} / \mathrm{g})$} \\
\hline & & & 304.9 & 169.7 \\
\hline Control Sample & 174.73 & 331.13 & 314.2 & 102.7 \\
\hline Biofield Energy Treated & 175.14 & 330.4 & 3.05 & -39.48 \\
\hline \% Change* & 0.23 & -0.22 & & Fusion \\
\hline
\end{tabular}

$\Delta \mathrm{H}$ : Latent heat of evaporation/decomposition, *denotes the \% change of the Biofield Energy Treated mercaptopurine with respect to the control sample.

However, the melting point and latent heat of fusion ( $\Delta \mathrm{H}$ fusion) of the Biofield Energy Treated mercaptopurine was decreased by $-0.22 \%$ and $-39.48 \%$ compared with the control sample (Table $3)$. Any change in the latent heat of fusion can be attributed to the disrupted molecular chains and the crystal structure [45]. From the results, it can be assumed that the Trivedi Effect ${ }^{\circledR}$-Consciousness Energy Healing Treatment might have disrupted the molecular chains and crystal structure of mercaptopurine. hence, the thermal stability of the treated 6-mercaptopurine sample was decreased compared to the control sample.

\section{Thermal Gravimetric Analysis (TGA) / Differential Ther- mogravimetric Analysis (DTG)}

The thermograms of the control and Biofield Energy Treated samples showed three steps of thermal degradation (Figure 3). The total weight loss of the treated 6-mercaptopurine was significantly increased by $9.72 \%$ compared to the control sample (Table 4 ). Therefore, the residue amount was significantly decreased by 79.89\% in the Biofield Energy Treated 6-mercaptopurine compared to the control sample (Table 4).
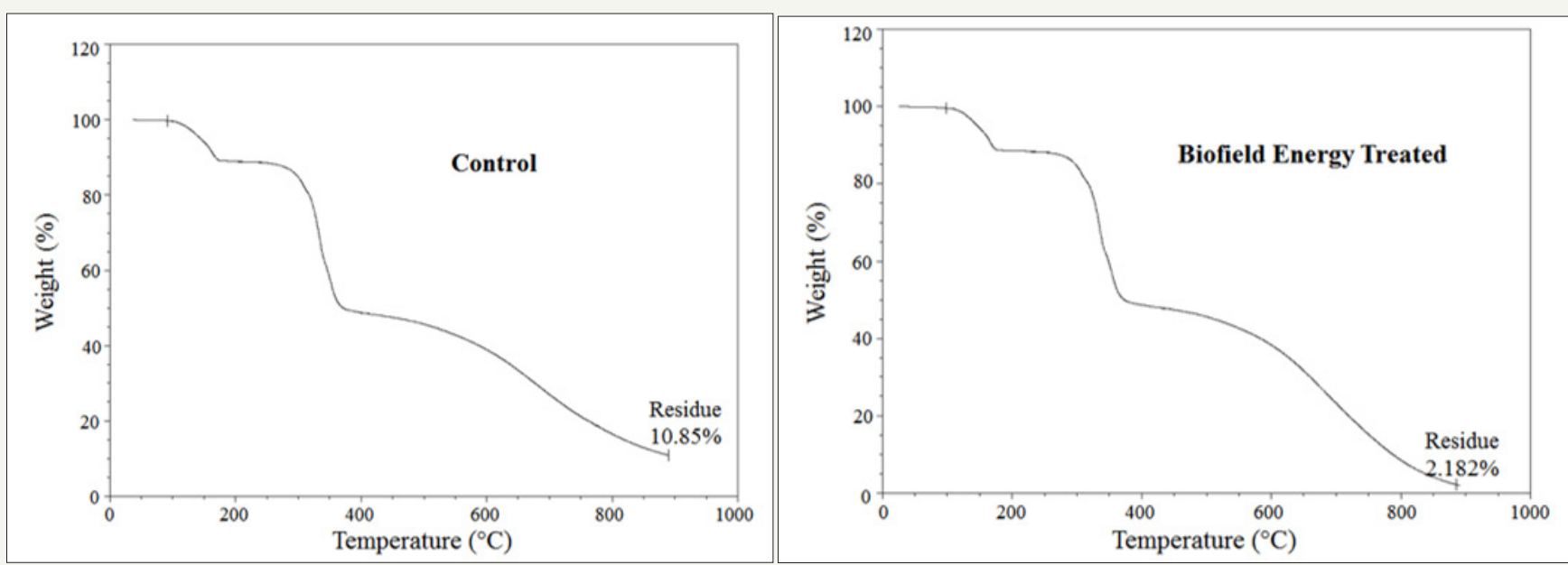

Figure 3: TGA thermograms of the control and Biofield Energy Treated mercaptopurine.

Table 4: TGA/DTG data of the control and Biofield Energy Treated samples of mercaptopurine.

\begin{tabular}{|c|c|c|c|c|c|}
\hline \multirow[t]{2}{*}{ Sample } & \multicolumn{2}{|c|}{ TGA } & \multicolumn{3}{|c|}{ DTG; $\operatorname{Tmax}\left({ }^{\circ} \mathrm{C}\right)$} \\
\hline & Total weight loss (\%) & Residue \% & $1^{\text {st }}$ Peak & $2^{\text {nd }}$ Peak & $3^{\text {rd }}$ Peak \\
\hline Control & 89.15 & 10.85 & 160.61 & 332.3 & 650.1 \\
\hline Biofield Energy Treated & 97.818 & 2.182 & 163.08 & 332.8 & 686.3 \\
\hline$\%$ Change* $^{*}$ & 9.72 & -79.89 & 1.54 & 0.13 & 5.56 \\
\hline
\end{tabular}

*denotes the \% change of the Biofield Energy Treated sample with respect to the control sample, $\mathrm{T}_{\max }=$ the temperature at which maximum weight loss takes place in TG or peak temperature in DTG.

The DTG of the control and Biofield Energy Treated 6-mercaptopurine also showed three peaks in the thermograms (Figure 4). The maximum thermal degradation temperature (Tmax) of the $1^{\text {st }}, 2^{\text {nd }}$, and $3^{\text {rd }}$ peaks of the Biofield Energy Treated sample altered by $1.54 \%, 0.13 \%$, and $5.56 \%$ compared with the control sample (Table 4). Overall, TGA/DTG data of mercaptopurine samples revealed that the thermal stability of the Biofield Energy Treated 6-mercaptopurine sample was increased compared with the control sample. 

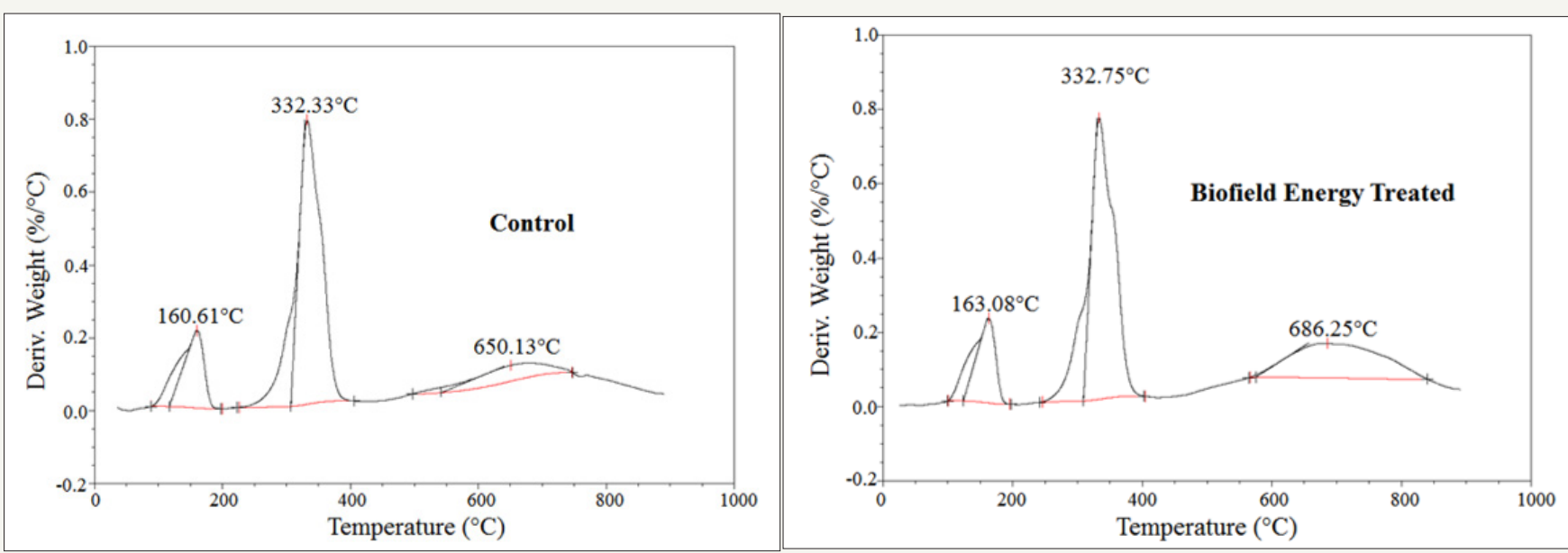

Figure 4: DTG thermograms of the control and Biofield Energy Treated mercaptopurine.

\section{Conclusion}

The Trivedi Effect ${ }^{\circledR}$-Consciousness Energy Healing Treatment has a significant effect on the particle size, surface area, crystallite size, and thermal properties of 6-mercaptopurine. The particle size values in the Consciousness Energy Healing Treated powder sample were significantly decreased by $5.72 \%, 5.16 \%, 3.75 \%$, and $4.54 \%$ at $d_{10}, d_{50}, d_{90}$, and $D(4,3)$ compared to the control sample. Therefore, the specific surface area of the Biofield Energy Treated powder sample was increased by $4.76 \%$ compared to the control sample. The PXRD peak intensities and crystallite sizes of the treated sample were significantly altered ranging from $-25 \%$ to $14.12 \%$ and $-35.09 \%$ to $71.3 \%$, respectively compared to the control sample. Unlike particle sizes, the average crystallite size of the Biofield Energy Treated sample was decreased by $2.77 \%$ compared with the control sample. The evaporation temperature and $\Delta$ Hevaporation of the Biofield Energy Treated sample were slightly increased by $0.23 \%$ and $3.05 \%$, respectively compared with the control sample. However, the melting point and $\Delta \mathrm{H}$ fusion of the Biofield Energy Treated sample was decreased by $-0.22 \%$ and $-39.48 \%$ compared with the control sample. The total weight loss was significantly increased by $9.72 \%$; hence the residue amount was significantly decreased by $79.89 \%$ in the Biofield Energy Treated sample compared with the control sample. The Tmax of the $1^{\text {st }}, 2^{\text {nd }}$, and $3^{\text {rd }}$ peaks of the Biofield Energy Treated sample were increased by $1.54 \%, 0.13 \%$, and $5.56 \%$ compared with the control sample. From the overall results, it was concluded that the Trivedi Effect ${ }^{\circledR}$-Consciousness Energy Healing Treatment might have generated a new polymorphic form of 6-mercaptopurine which may offer better solubility, dissolution, absorption, and bioavailability compared with the control sample. The Biofield Energy Treated 6-mercaptopurine would be very useful to design better pharmaceutical formulations that might offer better therapeutic response against acute lymphocytic leukemia, chronic myeloid leukemia, ulcerative colitis, Crohn's disease, and autoimmune diseases.

\section{Acknowledgement}

The authors are grateful to Central Leather Research Institute,
SIPRA Lab. Ltd., Trivedi Science, Trivedi Global, Inc., Trivedi Testimonials, and Trivedi Master Wellness for their assistance and support during this work.

\section{References}

1. Salser JS, Balis ME (1965) The mechanism of action of 6-mercaptopurine: I biochemical effects. Cancer Res 25: 539-543

2. https://www.drugbank.ca/drugs/DB01033.

3. Present DH, Korelitz BI, Wisch N, Glass JL, Sachar DB, et al. (1980) Treatment of Crohn's disease with 6-mercaptopurine: A long-term, randomized, double-blind study. N Engl J Med 302(18): 981-987.

4. Schmiegelow K, Glomstein A, Kristinsson J, Björk O (1997) Impact of morning versus evening schedule for oral methotrexate and 6-mercaptopurine on relapse risk for children with acute lymphoblastic leukemia. Nordic Society for Pediatric Hematology and Oncology (NOPHO). J Pediatr Hematol Oncol 19(2): 102-109.

5. Sack DM, Peppercorn MA (1983) Drug therapy of inflammatory bowel disease. Pharmacotherapy 3(3): 158-176.

6. WHO (2015) Model list of essential medicines, $19^{\text {th }}$ List, World Health Organization.

7. https://en.wikipedia.org/wiki/Mercaptopurine.

8. Yang JJ, Landier W, Yang W, Liu C, Hageman L, et al. (2015) Inherited NUDT15 variant is a genetic determinant of mercaptopurine intolerance in children with acute lymphoblastic leukemia. J Clin Oncol 33(11): 1235-1242.

9. Moriyama T, Nishii R, Perez-Andreu V, Yang W, Klussmann FA, et al. (2016) NUDT15 polymorphisms alter thiopurine metabolism and hematopoietic toxicity. Nature Genet 48(4): 367-373.

10. Lerner EI, Flashner-Barak M, Achthoven EV, Keegstra H, Smit R (2012) Formulations of 6-mercaptopurine. US patent US8188067 B2.

11. Tiphaine Ade B, Hjalgrim LL, Nersting J, Breitkreutz J, Nelken B, et al. (2016) Evaluation of a pediatric liquid formulation to improve 6-mercaptopurine therapy in children. Eur J Pharm Sci 83: 1-7.

12. https://pubchem.ncbi.nlm.nih.gov/compound/6-Mercaptopurine.

13. Chereson R (2009) Bioavailability, bioequivalence, and drug selection. In: Makoid CM, Vuchetich PJ, Banakar UV (Eds.), Basic pharmacokinetics ( $1^{\text {st }}$ edn), Pharmaceutical Press, London, UK.

14. Trivedi MK, Patil S, Shettigar H, Singh R, Jana S (2015) An impact of biofield treatment on spectroscopic characterization of pharmaceutical compounds. Mod Chem appl 3:159. 
15. Trivedi MK, Patil S, Shettigar H, Bairwa K, Jana S (2015) Spectroscopic characterization of chloramphenicol and tetracycline: An impact of biofield. Pharm Anal Acta 6: 395.

16. Branton A, Jana S (2017) Effect of the biofield energy healing treatment on the pharmacokinetics of 25-hydroxyvitamin $\mathrm{D}_{3}\left[25(\mathrm{OH}) \mathrm{D}_{3}\right]$ in rats after a single oral dose of vitamin $\mathrm{D}_{3}$. American Journal of Pharmacology and Phytotherapy 2(1): 11-18.

17. Trivedi MK, Branton A, Trivedi D, Nayak G, Lee AC, et al. (2017) An investigation of The Trivedi Effect ${ }^{\circledR}$-Energy of consciousness healing treatment to modulate the immunomodulatory effect of herbomineral formulation in male sprague dawley rats. Advances in Materials 5: 144153.

18. Trivedi MK, Mohan TRR (2016) Biofield energy signals, energy transmission and neutrinos. American Journal of Modern Physics 5 : 172-176.

19. Koithan M (2009) Introducing complementary and alternative therapies. J Nurse Pract 5: 18-20.

20. Rubik B (2002) The biofield hypothesis: Its biophysical basis and role in medicine. J Altern Complement Med 8(3): 703-717.

21. Barnes PM, Bloom B, Nahin RL (2008) Complementary and alternative medicine use among adults and children: United States, 2007. Natl Health Stat Report 12: 1-23.

22. Frass M, Strassl RP, Friehs H, Müllner M, Kundi M, et al. (2012) Use and acceptance of complementary and alternative medicine among the general population and medical personnel: A systematic review. Ochsner J 12(1): 45-56.

23. Dabhade VV, Tallapragada RMR, Trivedi MK (2009) Effect of external energy on the atomic, crystalline, and powder characteristics of antimony and bismuth powders. Bulletin of Materials Science 32: 471479.

24. Trivedi MK, Nayak G, Patil S, Tallapragada RM, Latiyal O (2015) Studies of the atomic and crystalline characteristics of ceramic oxide nano powders after bio field treatment. Ind Eng Manage 4: 161.

25. Trivedi MK, Nayak G, Patil S, Tallapragada RM, Mishra R (2015) Influence of biofield treatment on physicochemical properties of hydroxyethyl cellulose and hydroxypropyl cellulose. J Mol Pharm Org Process Res 3: 126.

26. Trivedi MK, Branton A, Trivedi D, Nayak G, Panda P, et al. (2016) Evaluation of the isotopic abundance ratio in biofield energy treated resorcinol using gas chromatography-mass spectrometry technique. Pharm Anal Acta 7: 481.

27. Trivedi MK, Branton A, Trivedi D, Nayak G, Bairwa K, et al. (2015) Impact of biofield treatment on spectroscopic and physicochemical properties of p-nitroaniline. Insights in Analytical Electrochemistry 1: 1-8.

28. Trivedi MK, Branton A, Trivedi D, Shettigar H, Nayak G, et al. (2015) Antibiogram typing of biofield treated multidrug resistant strains of Staphylococcus species. American Journal of Life Sciences 3: 369-374.

29. Trivedi MK, Branton A, Trivedi D, Shettigar H, Nayak G, et al. (2015) Antibiogram, biochemical reactions and genotyping characterization of biofield treated Staphylococcus aureus. American Journal of Bio Science 3: $212-220$

30. Trivedi MK, Patil S, Shettigar H, Mondal SC, Jana S (2015) The potential impact of biofield treatment on human brain tumor cells: A time-lapse video microscopy. J Integr Oncol 4: 141.
31. Trivedi MK, Patil S, Shettigar H, Gangwar M, Jana S (2015) In vitro evaluation of biofield treatment on cancer biomarkers involved in endometrial and prostate cancer cell lines. J Cancer Sci Ther 7: 253-257.

32. Trivedi MK, Branton A, Trivedi D, Nayak G, Gangwar M, et al. (2015) Effect of biofield energy treatment on chlorophyll content, pathological study, and molecular analysis of cashew plant (Anacardium occidentale L.). Journal of Plant Sciences 3: 372-382.

33. Trivedi MK, Branton A, Trivedi D, Nayak G, Mondal SC, et al. (2015) Evaluation of plant growth, yield and yield attributes of biofield energy treated mustard (Brassica juncea) and chick pea (Cicer arietinum) seeds. Agriculture, Forestry and Fisheries 4: 291-295.

34. Trivedi MK, Sethi KK, Panda P, Jana S (2017) A comprehensive physicochemical, thermal, and spectroscopic characterization of zinc (II) chloride using X-ray diffraction, particle size distribution, differential scanning calorimetry, thermogravimetric analysis/ differential thermogravimetric analysis, ultraviolet-visible, and Fourier transform-infrared spectroscopy. International Journal of Pharmaceutical Investigation 7: 33-40.

35. Trivedi MK, Sethi KK, Panda P, Jana S (2017) Physicochemical, thermal and spectroscopic characterization of sodium selenate using XRD, PSD, DSC, TGA/DTG, UV-vis, and FT-IR. Marmara Pharmaceutical Journal 21(2): 311-318

36. (1997) Desktop x-ray diffractometer miniflex. The Rigaku Journal 14: 29-36.

37.Zhang T, Paluch K, Scalabrino G, Frankish N, Healy AM, et al. (2015) Molecular structure studies of (1S,2S)-2-benzyl-2,3-dihydro-2(1Hinden-2-yl)-1H-inden-1-ol. J Mol Struct 1083: 286-299.

38. Langford JI, Wilson AJC (1978) Scherrer after sixty years: A survey and some new results in the determination of crystallite size. J Appl Cryst 11: 102-113.

39. Khadka P, Ro J, Kim H, Kim I, Kim JT, et al. (2014) Pharmaceutical particle technologies: An approach to improve drug solubility, dissolution and bioavailability. Asian J Pharm Sci 9: 304-316.

40. Raza K, Kumar P, Ratan S, Malik R, Arora S (2014) Polymorphism: The phenomenon affecting the performance of drugs. SOJ Pharm Pharm Sci $1: 10$.

41. Brittain HG (2009) In: Polymorphism in pharmaceutical solids in drugs and pharmaceutical sciences, $\left(2^{\text {nd }}\right.$ edn), Informa Healthcare, Volume 192, New York, USA

42. Censi R, Martino PD (2015) Polymorph Impact on the bioavailability and stability of poorly soluble drugs. Molecules 20(10): 18759-18776.

43. Blagden N, de Matas M, Gavan PT, York P (2007) Crystal engineering of active pharmaceutical ingredients to improve solubility and dissolution rates. Adv Drug Deliv Rev 59(7): 617-630.

44. Lv X, Zhao M, Wang Y, Hu X, Wu J, et al. (2016) Loading cisplatin onto 6-mercaptopurine covalently modified MSNS: A nanomedicine strategy to improve the outcome of cisplatin therapy. Drug Des Devel Ther 10: 3933-3946.

45.Zhao Z, Xie M, Li Y, Chen A, Li G, et al. (2015) Formation of curcumin nanoparticles via solution-enhanced dispersion by supercritical $\mathrm{CO}_{2}$. Int J Nanomedicine 10: 3171-3181. 

(c) (i) Creative Commons Attribution 4.0

For possible submissions Click Here

Submit Article

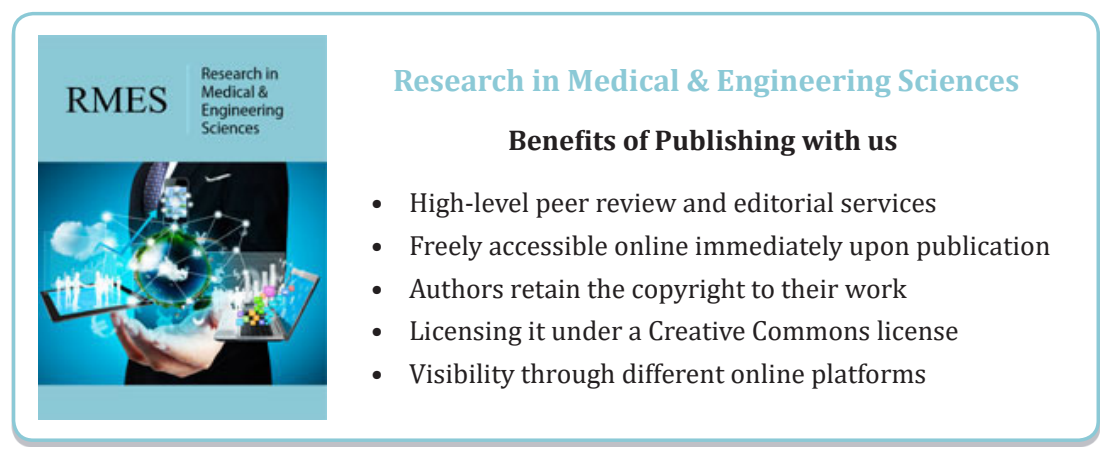

